\title{
Social networking in Bangladesh: Boon or curse for academic engagement?
}

\author{
Dey MOURI \\ University of Chittagong, Chittagong, Bangladesh \\ E-mail:mouridey@cu.ac.bd \\ Chowdhury ALI ARSHAD \\ University of Chittagong, Chittagong, Bangladesh
}

\begin{abstract}
The number of social networking services (SNSS) users in Bangladesh is increasing at an accelerating rate. There are many who argue that SNS usage is destroying the students' future by diminishing their academic engagement. The authors aim to investigate whether there is any relationship between students' academic performance and their SNS usage. The study chose Facebook as a representative of SNSs because this is the most popular platform for online social connectivity and conducted a survey regarding the usage of Facebook among students of Business Administration from three private Bangladeshi private universities. The research results show that Facebook can be used for at least 21 academic tasks or goals and that these can be grouped into six major factors. Moreover, students opine that their online socializing does not reduce their study time, instead it helps them get the latest study related information, sharing courses, class schedules etc. After running a regression analysis, the authors conclude that the students' level of engagement with the academic life through Facebook does not influence their academic results. The reason for this insignificant relation between academic results and academic engagement through SNSs may be due to the non-diversified course curriculum, the traditional way of delivering lectures and evaluating, limited study materials, nonreceptiveness to technology-based learning etc. However, the authors propose to include SNSs as a study tool as it is a popular media and to conduct further research to better understand the effective way of using it in the education system.
\end{abstract}

Key words: social networking services (SNSs), academic engagement, Bangladesh, academic achievement.

Please cite the article as follows: Mouri, D. and Ali Arshad, C. (2016), "Social networking in Bangladesh: Boon or curse to academic engagement?", Management \& Marketing. Challenges for the Knowledge Society, Vol. 11, No. 1, pp. 380-393, DOI: 10.1515/mmcks-2016-0004.

\section{Introduction}

People have been using the internet for virtual interaction since the 1980s, but it is only in the last two decades that social networking services have escalated and their use has become a widespread practice - particularly amongst young people (Collin et al., 2011). Facebook (FB) as a networking system has revolutionized the way society connects and interacts and it has established a new era of social sharing since its invention in 2004 . There are 1.9 billion active Facebook users in the world at present (Facebook as of 28 January 2015) with an increase of 26 percent year-over-year. Each second, five new 
profiles are created (ALL Facebook, 2012). It is currently considered the most popular platform for online social networking among university students (Kabilan et al., 2010; Junco, 2012; Facebook review, 2015) and it has strong influence over millions of students (Thompson, 2007).

Facebook can be defined as a web-based service that allows individuals to create a public or semi-public profile within a close-bound system, (2) articulate a list of other users with whom they share a connection, and (3) view and traverse their list of connections and those made by others within the system (Boyd and Ellison, 2007). It is a virtual platform for creating and maintaining relationships with friends and relatives, arranging social events, mobilizing community leadership, sharing information etc. Facebook allows users to communicate with others in many ways. The most frequently used forms of communication include: profile updates, comments on photos or other posts, posting public messages to others or wall-style messages, social network based instant messaging (Nielson, 2010). In addition to communication, SNS facilitate the creation and sharing of various forms of content including blogs, video, photos and more.

In Bangladesh, the number of Facebook users has crossed the 10 million threshold and it is still increasing each day. Facebook is very popular among the young people of Bangladesh irrespective of their location or education level. It is worth mentioning that $73 \%$ of the Facebook users in Bangladesh have between 13 and 25 years, meaning they are students either at secondary school or at university. As prime users, they are spending a significant time on Facebook. The principal concern of this study is to find out the role of Facebook as a beneficial tool for enhancing the academic performance of the university students.

\section{Literature review and rationale of the study}

Social networking sites such as Facebook have been the subject of many recent debates within the educational community. Whilst growing numbers of educators accept the potential of social networking to connect learners with their studies, others fear that such applications demolish young peoples' engagement with the "traditional" education system. Facebook is also being used as an instrument for sharing learning experiences, building learning communities besides general communication. It engages students in online learning communities using technologies familiar to and accepted by their generation (Oradini and Saunders, 2008). SNS help deepen learning, act as memory aids and provide students with the freedom to express their opinions thus lessening pressure and increasing communication and socialization (Ballera et al., 2013). Since it has quickly become the social networking site of choice for university students and an integral part of the "behind the scenes" university experience (Selwyn, 2007), it is essential to integrate Facebook within the educational framework in order to attain more robust learning and teaching opportunities. Facebook can be used for collaborative learning, and has become a passion for students. In addition, students like to share, collaborate or work as a team. On the other hand, youth, the life stage of creativity, innovation, exploration of social and cultural life, cheerfulness, physical activity, shaping of personality and social skills seems to be eroded by the evil materialized in the form of social networking websites (Chawada et al., 2013).

Bosch (2009) showed the potential positive benefits of using Facebook in teaching and learning, particularly for the development of educational micro-communities. The 
MMCKS findings indicated that the students and the lecturers were positive about using Facebook as a "social" platform to exchange knowledge and information and build relationships with one another that extend beyond the boundaries of the classroom and the textbook. Hence, Facebook connectivity and Facebook communication between the students and the lecturers enable a better rapport between them (Yeo, 2014). Students seem to associate the Facebook websites of teachers high in self-disclosure with higher levels of motivation and affective learning and a more positive classroom climate (Mazer et al., 2007). According to Pascarella and Terrenzini (1991), some of the most effective faculty members are those that create an informal relationship with their students. Over recent decades, numerous studies have suggested that student-faculty interaction has a notable impact on learning outcomes, both in the intellectual and the social realm (Endo and Harpel, 1982). It was found in a survey carried out among 300 undergraduate students at the University Sains Malaysia (USM), Penang, that the students believed FB could be utilized as an online environment to facilitate the learning of English (Kabilan et al., 2010). Studies showed that social networking tools support educational activities by making interaction, collaboration, active participation, information and resource sharing, and critical thinking possible (Ajjan and Hartshorne, 2008; Mason, 2006; Selwyn, 2007).

Students today demand more autonomy, connectivity, interaction and socioexperiential learning opportunities in their learning contexts (McLoughlin and Lee, 2007). But, Facebook has not yet proved its positive impact on students' academic engagement. Results indicate that the level of Facebook usage was significantly negatively correlated negative with the level of academic engagement and positively correlated with the amount of time spent in co-curricular activities (Junco, 2012). Time spent on Facebook was negatively related to overall GPA and time on Facebook was also negatively related to time spent preparing for class (idem). In a study conducted by Kirschner and Karpsinki (2010), it was showed that Facebook users reported having lower GPAs and spending fewer hours per week studying in comparison to nonusers. Facebook is not yet accepted as a tool of academic engagement. Students think that use of Facebook is most importantly for social reasons, not for formal teaching purposes (Madge et al., 2009).

Millions of students of Bangladesh have regular interactions on Facebook with friends, teachers, and senior students of the institution, but a very insignificant portion of that interaction is dedicate to academic purposes. Although Facebook is not socially accepted as a means of improving academic performance, when asked students state that Facebook can play this role (Jahan and Zabed Ahmed, 2012). As very few studies have been conducted in Bangladesh to explore the nature of the relationship between Facebook usage and academic engagement, this study minimizes the research gap by focusing on the ways in which Facebook can be used for academic purposes and how these uses impact academic results represented by grade point average.

\section{Research methodology}

Generally it is assumed that the more students use SNS the more this will negatively affect their academic results in terms of GPA and their psychological wellbeing (Chawada et al., 2013; Liu and Tsai, 2012). Again, SNS can be a good medium of study for those students who are less attentive or physically challenged (Green et al., 2007; Collin et al., 2011). On 
the contrary, some researches support that there is no relationship between SNS use and academic results (Ahn, 2011).

In Bangladesh, SNS are very popular among the students. Sometimes, they also use it in the classroom. There are no institutional barriers or guidelines with regards to the way in which students use SNS. It is the students' choice how they will engage with this medium. Therefore, the main objective of this study is to examine the impact of SNS use on academic results and the secondary objectives are (a) to identify the level of involvement of SNS in various academic activities and (b) to examine the relationship between academic results and academic involvement of SNS.

\section{Description of the sample}

There are eight private universities located in Chittagong city, Bangladesh. One of them was founded in 2013. Hence, this university was not considered part of the study population. The number of business students of the remaining universities is approximately 8,000. Since this paper examined the relationship between students' results and their engagement with SNS, the authors took third semester and forth semester students as the most appropriate population. The standard size of the class is about 40 . The stratified sampling technique has been followed to select the respondents and 280 questionnaires were sent, out of which only 135 were returned fully filled in. The average age of the students is 21 years. There were two and a half times more male respondents than female respondents. Almost all the respondents live in a city or their home town is in a city. 98\% respondents use SNS while only 2\% of them do not use SNS. 117 respondents out of 135 disclose their current results and their average GPA is 3.81 (scale 4) which indicates an excellent result.

\section{Questionnaire design}

There are four sections in the questionnaire: (I) socio-demographic characterization of the students, (II) SNS usage, (III) academic engagement and (IV) social inclusion are measured on the basis of 5-point Likert scale. Due to insufficient responses with respect to social inclusion, this section was omitted. From various research article, 21 variables are chosen to identify students' academic engagement with SNS. The questionnaire is presented in Annex 1.

\section{Data reliability and sufficiency}

Reliability shows the strong or weak consistency of a set of items (variables) as a group that are considered as a hypothesis to measure the study concept (Rahman et al., 2013). Cronbach's alpha is a popularly applied technique to measure this internal consistency (Hair et al., 2003; Cooper and Schindler, 2001; Malhotra, 2002). It is considered to be a measure of scale reliability. In this study, the consistency of 21 items of the variable "academic engagement" was measured by using statistical package for social science (SPSS, version-21.0). The value of Cronbach's alpha value was 0.772 , which can be considered to be acceptable (Kline, 2005). The value for KMO sampling adequacy is 0.733 which is more than an acceptable range. Thus it can be said that data is sufficient to analyze the research objectives. Moreover, Bartlett's Test of Sphericity is also proved significant. 
Table 1. Data sufficiency test

\section{Research results}

\section{General description of SNS usage for academic purposes}

The questionnaire contained 21 items referring to academic usage of SNS and in table 2 we present the average scores for these items which lie between 3.31 and 4.48 (on a scale from 1 to 5). The lowest mean score was obtained by item A9 (SNS kills study time) while the highest mean score was registered by A6 (SNS can be used for getting latest information related with my studies). Four items (A9, A16, A17, A7) scored less than 3.5 and five variables (A4, A3, A5, A1, A6) scored more than 4.0. The remaining twelve variables have similar average scores (approx. 3.75). Table 2 presents the standard deviation of all the items which are very low, except for item A6, which means that the students' opinions are very similar. The general tendency shows a positive use of SNS by the undergraduate business students of private universities. However, the academic activities such as the participation in study groups for difficult courses, preparation of class notes and continuation of class discussion have been ranked among the last in the list of Facebook potential academic usages.

Table 2. Descriptive features of items' scores

\begin{tabular}{|l|l|r|r|r|}
\hline Item & Content & Mean & SD & No. \\
\hline A9 & SNS kills study time & 3.31 & 1.18075 & 132 \\
\hline A16 & Establish interaction between teachers and parents & 3.34 & 0.97496 & 123 \\
\hline A17 & Minimize cultural gap & 3.35 & 1.11627 & 125 \\
\hline A7 & $\begin{array}{l}\text { SNS is mainly used for the purpose of searching friends and } \\
\text { contacts }\end{array}$ & 3.44 & 1.1856 & 129 \\
\hline A21 & Study groups for difficult courses & 3.52 & 1.083 & 129 \\
\hline A19 & Social learning environment & 3.53 & 0.97694 & 126 \\
\hline A2 & Use of SNS for communication with teachers for studies & 3.64 & 1.14006 & 132 \\
\hline A20 & Continuation of class discussion & 3.7 & 0.96924 & 124 \\
\hline A12 & Useful for finding internship vacancies & 3.71 & 0.92447 & 124 \\
\hline A14 & Provide necessary sources to prepare notes & 3.73 & 1.0049 & 124 \\
\hline A15 & Useful to solve communication problem & 3.73 & 1.16703 & 128 \\
\hline A13 & Useful for searching scholarship positions & 3.77 & 1.1027 & 128 \\
\hline A8 & SNS for getting new academic ideas & 3.82 & 0.84604 & 127 \\
\hline A11 & SNS should be fully integrated to the higher studies & 3.83 & 0.99836 & 129 \\
\hline A18 & Create awareness & 3.89 & 1.07522 & 127 \\
\hline A10 & Academic networking for national and international level & 3.92 & 1.00933 & 127 \\
\hline A4 & SNS can be a useful mode of sharing experiences and research & 4 & 0.94051 & 131 \\
\hline findings & SNS can used for sharing academic information & 4.01 & 1.0659 & 133 \\
\hline A5 & Sharing academic events/notices & 4.05 & 0.97122 & 131 \\
\hline A1 & Use of SNS for communication with students for studies & 4.16 & 0.86323 & 133 \\
\hline
\end{tabular}




\section{Factor analysis}

The main objective of factor analysis is to uncover latent variables by grouping similar items together. It also removes the multicolinearity problem of independent variables. In this article, 21 items have been used which are correlated with each other. Stevens (2002) states that with 30 or more variables and communalities greater than 0.7 for all variables, different solutions are unlikely; however, with fewer than 20 variables and any low communality $(<0.4)$ differences can occur. According to Stevens (2002), for a sample size of 50 a loading of 0.722 can be considered significant, for 100 the loading should be greater than 0.512 , for 200 it should be greater than 0.364 , for 300 it should be greater than 0.298 , for 600 it should be greater than 0.21 , and for 1000 it should be greater than 0.162 . This article considers 21 variables and a sample of 135 . Hence, 0.512 has been considered as basis of factor.

Table 3 represents the factor analysis of selected twenty-one variables and items included in each component. Only six components were identified as major variables. According to the nature of the included elements, the components were renamed to reflect their characteristics.

Table 3. Factor analysis results

\begin{tabular}{|c|c|c|c|c|c|}
\hline Component 1 & Component 2 & Component 3 & Component 4 & Component 5 & Component 6 \\
\hline $\begin{array}{l}\text { Academic } \\
\text { networking } \\
\text { for national } \\
\text { and } \\
\text { international } \\
\text { level (.713) }\end{array}$ & $\begin{array}{l}\text { Communicate } \\
\text { with students } \\
\text { for studies } \\
(.727)\end{array}$ & $\begin{array}{l}\text { SNS can used } \\
\text { for sharing } \\
\text { academic } \\
\text { information } \\
(.559)\end{array}$ & $\begin{array}{l}\text { Useful to } \\
\text { solve } \\
\text { communicatio } \\
\text { n problem } \\
(.582)\end{array}$ & $\begin{array}{l}\text { SNS is mainly } \\
\text { used for the } \\
\text { purpose of } \\
\text { searching } \\
\text { friends and } \\
\text { contacts } \\
(.667)\end{array}$ & $\begin{array}{l}\text { SNS can be } \\
\text { used for } \\
\text { getting latest } \\
\text { information } \\
\text { related with } \\
\text { my studies } \\
(.513)\end{array}$ \\
\hline $\begin{array}{l}\text { Useful for } \\
\text { finding } \\
\text { internship } \\
\text { vacancies } \\
(.614)\end{array}$ & $\begin{array}{l}\text { Communicate } \\
\text { with teachers } \\
\text { for studies } \\
(.715)\end{array}$ & $\begin{array}{l}\text { SNS can be a } \\
\text { useful mode of } \\
\text { sharing } \\
\text { experiences } \\
\text { and research } \\
\text { findings } \\
(.753)\end{array}$ & $\begin{array}{l}\text { Minimize } \\
\text { cultural gap } \\
(.756)\end{array}$ & $\begin{array}{l}\text { SNS kills study } \\
\text { time (.781) }\end{array}$ & $\begin{array}{l}\text { SNS should be } \\
\text { fully integrated } \\
\text { to the higher } \\
\text { studies (.559) }\end{array}$ \\
\hline $\begin{array}{l}\text { Useful for } \\
\text { searching } \\
\text { scholarship } \\
\text { positions } \\
(.745)\end{array}$ & $\begin{array}{l}\text { Provide } \\
\text { necessary } \\
\text { sources to } \\
\text { prepare notes } \\
(.520)\end{array}$ & $\begin{array}{l}\text { Sharing } \\
\text { academic } \\
\text { events/notices } \\
(.796)\end{array}$ & $\begin{array}{l}\text { Social } \\
\text { learning } \\
\text { environment } \\
(.521)\end{array}$ & & \\
\hline $\begin{array}{l}\text { Create } \\
\text { awareness } \\
(.521)\end{array}$ & $\begin{array}{l}\text { Establish } \\
\text { interaction } \\
\text { between } \\
\text { teachers and } \\
\text { parents }(.772)\end{array}$ & $\begin{array}{l}\text { SNS for getting } \\
\text { new academic } \\
\text { ideas }(.617)\end{array}$ & & & \\
\hline $\begin{array}{l}\text { Continuation } \\
\text { of class } \\
\text { discussion }\end{array}$ & & & & & \\
\hline
\end{tabular}


Hence component 1 relates to 'outside academic information', component 2 represents 'communication with related parties for studies', component 3 shows 'sharing academic ideas, news and experiences', component 4, component 5 and component 6 can be called as 'social and cultural improvement through communication', 'non-academic engagement' and 'latest information about higher studies' respectively. Commonly, all components except component 5 have direct and indirect positive impact on students' academic performance. However, component 5 is an indicator to measure the negative impact on academic performance.

Again, factor analysis is effective if the factors can properly explain the variation of variables. Kaiser (1960) recommends with eigenvalues greater than 1 is ideal because it can explain a substantial amount of variation. However, an eigenvalue greater than 0.7 is also acceptable (Jolliffe, 1972, 1986). In this regard, Table 4 discloses the eigenvalue of six components before extraction and after extraction and considers Kaiser's recommendation.

Table 4. Eigenvalue before extraction and after extraction

\begin{tabular}{|c|c|c|c|c|c|c|c|c|c|}
\hline \multirow[b]{2}{*}{ 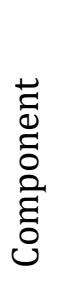 } & \multicolumn{3}{|c|}{ Initial Eigenvalues } & \multicolumn{3}{|c|}{$\begin{array}{l}\text { Extraction Sums of Squared } \\
\text { Loadings }\end{array}$} & \multicolumn{3}{|c|}{$\begin{array}{l}\text { Rotation Sums of Squared } \\
\text { Loadings }\end{array}$} \\
\hline & Total & 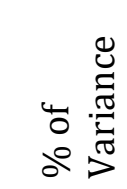 & 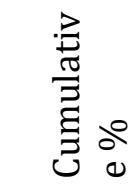 & Total & 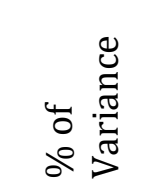 & 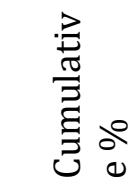 & Total & 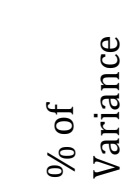 & 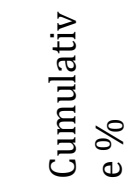 \\
\hline 1 & 5.600 & 26.666 & 26.666 & 5.600 & 26.666 & 26.666 & 4.053 & 19.300 & 19.300 \\
\hline 2 & 2.097 & 9.985 & 36.651 & 2.097 & 9.985 & 36.651 & 3.644 & 17.351 & 36.651 \\
\hline 3 & 1.521 & 7.242 & 43.893 & 1.521 & 7.242 & 43.893 & 2.523 & 12.014 & 48.665 \\
\hline 4 & 1.306 & 6.220 & 50.113 & 1.306 & 6.220 & 50.113 & 2.120 & 10.097 & 58.762 \\
\hline 5 & 1.246 & 5.931 & 56.044 & 1.246 & 5.931 & 56.044 & 1.490 & 7.097 & 65.859 \\
\hline 6 & 1.119 & 5.327 & 61.371 & 1.119 & 5.327 & 61.371 & 1.224 & 5.827 & 71.686 \\
\hline
\end{tabular}

Source: Authors' own research.

From the table, it is seen that retained factors can explain total $61.371 \%$ variation before extraction and $71.686 \%$ after extraction.

\section{Regression analysis}

To measure the relationship between academic uses of SNS and students' academic performance, two different multi-variable regression models have been run. First, considering six components as independent variables and secondly all the twenty one items independently. Both models have proved an insignificant relationship between students' results and their academic engagement with SNS.

Model 1 shows that the independent variables explain only 4.1\% of variation of the dependent variables (Table 5). The adjusted R-square value is negative. All individual factors are proved insignificant for t-test. However, factor 5 has a negative beta co-efficient and other factors have a positive beta co-efficient. ANOVA test also shows an insignificant relationship. 
Table 5. Model 1 summary

\begin{tabular}{|c|c|c|c|c|c|}
\hline \multicolumn{6}{|c|}{ Coefficients $^{a}$} \\
\hline \multirow[t]{2}{*}{ Model 1} & \multicolumn{2}{|c|}{$\begin{array}{l}\text { Unstandardized } \\
\text { Coefficients }\end{array}$} & \multirow{2}{*}{$\begin{array}{c}\begin{array}{l}\text { Standardized } \\
\text { Coefficients }\end{array} \\
\text { Beta } \\
\end{array}$} & \multirow[t]{2}{*}{$\mathrm{t}$} & \multirow[t]{2}{*}{ Sig. } \\
\hline & $\mathrm{B}$ & Std. Error & & & \\
\hline (Constant) & 3.805 & .076 & & 50.105 & .000 \\
\hline REGR factor score 1 for analysis 1 & .021 & .076 & .030 & .278 & .782 \\
\hline REGR factor score 2 for analysis 1 & .126 & .076 & .180 & 1.662 & .100 \\
\hline REGR factor score 3 for analysis 1 & .018 & .075 & .026 & .240 & .811 \\
\hline REGR factor score 4 for analysis 1 & .047 & .077 & .067 & .612 & .542 \\
\hline REGR factor score 5 for analysis 1 & -.030 & .075 & -.043 & -.398 & .692 \\
\hline REGR factor score 6 for analysis 1 & .009 & .078 & .012 & .114 & .910 \\
\hline
\end{tabular}

Model Summary

\begin{tabular}{|c|c|c|c|c|}
\hline \multirow{2}{*}{ Model 1 } & $\mathrm{R}$ & $\mathrm{R}$ Square & Adjusted R Square & $\begin{array}{c}\text { Std. Error of } \\
\text { the Estimate }\end{array}$ \\
\cline { 2 - 5 } & $.204^{\mathrm{a}}$ & .041 & -.029 & .71487 \\
\hline
\end{tabular}

a. Predictors: (Constant), REGR factor score 6 for analysis 1, REGR factor score 1 for analysis 1 , REGR factor score 3 for analysis 1, REGR factor score 2 for analysis 1, REGR factor score 5 for analysis 1, REGR factor score 4 for analysis 1

\begin{tabular}{|c|c|c|c|c|c|}
\hline \multicolumn{6}{|c|}{ ANOVA $^{a}$} \\
\hline Model 1 & Sum of Squares & $\mathrm{df}$ & Mean Square & $\mathrm{F}$ & Sig. \\
\hline Regression & 1.812 & 6 & .302 & .591 & $.737^{b}$ \\
\hline Residual & 41.906 & 82 & .511 & & \\
\hline Total & 43.717 & 88 & & & \\
\hline \multicolumn{6}{|c|}{ a. Dependent Variable: Result } \\
\hline \multicolumn{6}{|c|}{$\begin{array}{l}\text { b. Predictors: (Constant), REGR factor score } 6 \text { for analysis } 1 \text {, REGR factor score } 1 \text { for analysis } 1 \text {, } \\
\text { REGR factor score } 3 \text { for analysis 1, REGR factor score } 2 \text { for analysis } 1 \text {, REGR factor score } 5 \text { for } \\
\text { analysis } 1 \text {, REGR factor score } 4 \text { for analysis } 1\end{array}$} \\
\hline
\end{tabular}

Source: Authors' own research.

Similarly, Model 2 based on twenty on 21 independent variables to measure whether there is any relationship between students' academic results and their SNS engagement. Table 6 provides a summary of model 2. This model indicates that the independent variables can explain only $21.7 \%$ of dependent variables. The adjusted Rsquare is also negative which entails that there is no relationship between the dependent and the independent variables.

Table 6. Summary of Model 2

\begin{tabular}{|l|c|c|c|c|}
\hline \multicolumn{4}{|c|}{ Model Summary } \\
\hline
\end{tabular}

Vol. 11, No. 1, Spring, pp. 380-393, ISSN 1842-0206| Management \& Marketing. Challenges for the Knowledge Society 
academic ideas, establish interaction between teachers and parents, Useful for searching scholarship positions, SNS can be a useful mode of sharing experiences and research findings, Use of sns for communication with students for studies, useful to solve communication problem, SNS can used for sharing academic information, continuation of class discussion

Source: Authors' own research.

\section{Discussions}

According to these regression models, it is observed that there is no significant relationship between students' academic results and engagement with SNSs. Although descriptive statistics show that students use SNS for positive academic purposes, an in-depth analysis showed that there is no discernable impact of SNS on academic results. There may be several reasons for the lack of a significant result. The respondents are the business administration students of different private universities who use SNSs mainly for entertainment, sharing news and ideas of innovative business plan, class notes or schedule of class time. These matters are not directly related to the academic syllabus. In general, this may help the students to solve case studies and write presentation. In GPA calculation, this represents only $10 \%$. Secondly, there isn't any institutional engagement with SNSs to improve their academic usage or to solve academic problems. In some cases, students do not accept professors on their friend lists to avoid academic engagement. Thirdly, the contents of academic syllabus are too short so that they can easily manage academic examinations. As a consequence, their results are not hampered by excessive engagement with SNSs. Finally, students' results, in terms of GPA, do not express their extra-curricular performances such as winner of quiz test, essay writing competitions, improvement in IT usage, development in communication skills etc.

\section{Conclusions}

According to Collin et al. (2011) the benefits of using SNSs are media literacy, creativity, individual identity and self-expression, strengthening interpersonal relationships, civic engagement and political participation (pp. 13-16). They also explained the academic benefits by referring to formal and informal education. As formal education, blogs can be used in e-learning education system to improve rapport, motivation and engagement between teachers and students (Mazer et al., 2007). Informally, it can also facilitate learning and skill development by supporting peer to peer learning of knowledge and skills, collaboration, diverse cultural expression, the development of skills valued in the modern workplace and a more empowered conception of citizenship (Ito et al., 2006). Moreover, this paper depicts SNS as a learning space for young people who struggle in a traditional setting (Green et al., 2007).

As a social networking site, Facebook has become a popular medium of communication among the people of Bangladesh irrespective of profession, age, income level, gender, ethnicity etc. because of its easy access, low costs, availability of variety of information and a room for expressing of their own opinions. For investigation, the authors considered students of private universities because private universities emphasize modern equipment and facilities as learning tools. In this regard, the study identified 21 academic issues for which students are connected to SNS. According to the questionnaire responses, students think that the use of SNS enhances their knowledge, develops communication 
skills, provides opportunity to share academic lessons, class schedules etc. This implies a positive academic performance.

After factor analysis we regrouped the 21 items into 6 variables. Regression analysis suggests that these variables do not have any significant impact on academic results. This may happen due to traditional evaluation system of results or small contents of syllabus that do not hamper preparation time for examination. Since it will be very hard to prevent students from using social networking services, institutions should change their traditional academic strategy by including SNSs as a medium of education to receive the benefits we have mentioned throughout the paper.

\section{References}

Ahn, J. (2011),"The effect of social network sites on adolescents' social and academic development: Current theories and controversies", Journal of the American Society for Information Science and Technology, Vol. 62, No. 8, pp. 1435-1445.

Ballera, M., Lukandu, I.A. and Radwan, A. (2013), "Collaborative problem solving using public social network media: Analyzing student interaction and its impact to learning process", International Journal of Digital Information and Wireless Communications, Vol. 3, No. 1, pp. 25-42.

Bartlett-Bragg, A. (2006), "Reflections on pedagogy: Reframing practice to foster informal learning with social software", available at: www.dream.sdu.dk/uploads/files/Anne \%20Bartlett-Bragg.pdf (Accessed November 12, 2015)

Bosch T.E. (2009), "Using online social networking for teaching and learning: Facebook use at the University of Cape Town", Communication: South African Journal for Communication Theory and Research, Vol. 35, No. 2, pp.185-200.

Boyd, D.M. and Ellison, N.B. (2007), "Social network sites: Definition, history and scholarship", Journal of Computer-Mediated Communication, Vol. 13, pp. 210-230.

Chawada, B.L., Choksi, R.P., Choksi, S.B., Dari, U.T., Pawar, A.B. and Bansal, R.K. (2013),"Addiction to social networking websites and its effect on life course of college going students in Surat city", National Journal of Community Medicine, Vol. 1, No. 2, pp. 174-175.

Collin, P., Rahilly, K., Richardson, I. and Third, A. (2011), "The benefits of social networking services: A literature review", Cooperative Research Centre for Young People, Technology and Wellbeing, pp. 1-29.

Cooper, D. and Schindler, P. (2001), Business research methods, McGraw-Hill, Sydney.

Endo, J.J. and Harpel, R.L. (1982),"The effect of student-faculty interaction on students educational outcomes", Research in Higher Education, Vol. 16, No. 2, pp. 115-138.

Green, H., Facer, K., Rudd, T., Dillon, P. and Humphreys, P. (2007), Personalization and digital technologies, Futurelab, Bristol.

Hair, J., Anderson, R., Tatham, R. and Black, W. (2003), Multivariate data analysis with readings, Prentice Hall, New Jersey.

Ito, M., Okabe, D. and Matsuda, M. (2006), Personal, portable, pedestrian, MIT Press, Massachusetts.

Jahan, I. and Zabed Ahmed, S. (2012),"Students' perceptions of academic use of social networking sites: a survey of university students in Bangladesh", Information Development, Vol. 28, No. 3, pp. 235-247. 
MMCKS Jolliffe, I.T. (1972),“Discarding variables in a principal component analysis, I: Artificial data", Applied Statistics, Vol. 21, pp. 160-173.

Jolliffe, I.T. (1986), Principal component analysis, Springer, New York.

Junco, R. (2012a),"The relationship between frequency of Facebook use, participation in Facebook activities, and student engagement", Computers \& Education, Vol. 58, No. 1, pp. 162-171.

Junco, R. (2012b),"Too much face and not enough books: The relationship between multiple indices of Facebook use and academic performance", Computers in human behavior, Vol. 28, No. 1, pp. 187-198.

Kabilan, M.K., Ahmad, N. and Abidin, M.J.Z. (2010),"Facebook: An online environment for learning of English in institutions of higher education?", The Internet and Higher Education, Vol. 13, No. 4, pp. 179-187.

Kabir, T., Akter, S. and Ferdus, Z. (2015),"Exploitation of social networking sites and its impacts on students' academic results: A quest for correlation or misspecification in Bangladesh", Journal of Business and Technology, Vol. 9, No. 1, pp. 23-51.

Kaiser, H.F. (1960),"The application of electronic computers to factor analysis", Educational and psychological measurement, Vol. 20, pp. 141-151.

Kalra, R.K. and Manani, P. (2013),"Effect of social networking sites on academic achievement among introverts and extroverts", Asian Journal of Social Sciences \& Humanities, Vol. 2, No. 3, pp. 401-406.

Karpinski, A.C. (2009),"A description of Facebook use and academic performance among undergraduate and graduate students", paper presented at the Annual Meeting of the American Educational Research Association, San Diego, California.

Kajornboon, A.B. (2004),"The effect of using social networking assisted interaction between peer and teacher in English language learning", available at: www.litu.tu.ac. th/journal/FLLTCP/Proceeding/611.pdf (Accessed December 2, 2015).

Kessler, S. (2010), "The case of social media in schools", available at: www.mashable.com/2010/09/29/social-media-in-school (Accessed November 12, 2015).

Kirschner, P.A. and Karpinski, A.C. (2010),"Facebook and academic performance", Computers in human behavior, Vol. 26, No. 6, pp. 1237-1245.

Kline, R.B. (2005), Principles and practice of structural equation modeling, Guilford press, New York.

Liu, Y. and Tsai, Y. (2012),"The impact of social networking services (SNS) on college students' social relationship and private life", International Journal of Arts and Commerce, Vol. 1, No. 4.

Madge, C., Meek, J., Wellens, J. and Hooley, T. (2009),"Facebook, social integration and informal learning at university: It is more for socializing and talking to friends about work than for actually doing work", Learning, Media and Technology, Vol. 34, No. 2, pp. 141-155.

Malhotra, N.K. (2002), Marketing research: an applied orientation, Pearson Education Asia, New Delhi.

Mazer, J.P., Murphy, R.E. and Simonds, C.J. (2007),"I'll see you on "Facebook": The effects of computer-mediated teacher self-disclosure on student motivation, affective learning, and classroom climate", Communication Education, Vol. 56, No. 1, pp. 1-17. 
McLoughlin, C. and Lee, M. (2007),"Mapping the digital terrain: New media and social software as catalysts for pedagogical change, In: Proceedings Ascilite, Melbourne.

Nahar, Q. (2015),"Perception of personal behavior of Facebook users: A study on the students of private universities in Bangladesh", DIU Journal of Humanities and Social Science, Vol. 2, pp. 177-192.

Nielson (2010), The Australian Internet and Technology Report, Edition 12, The Nielson Company.

Oradini, F. and Saunders, G. (2008),"The use of social networking by students and staff in higher education", paper presented at the iLearning Forum, Paris, available at: www.eifel.org/publications/proceedings/ilf08/contributions/improving-quality-oflearning-withtechnologies/Oradini_Saunders.pdf (Accessed November 23, 2015).

Pascarella, E. and Terenzini, P. (1991), How college affects students, Jossey-Bass, San Francisco.

Rahman, I., and Rahman, S. (2013),"Online discussion forum and Facebook: Students' perceptions and interests on learning in tertiary level education in Bangladesh", paper presented at the International Conference on Tertiary Education (ICTERC 2013) Daffodil International University, Dhaka, Bangladesh 19-21 January 2013.

Selwyn, N. (2007), “Screw blackboard...do it on Facebook!: An investigation of students' educational use of Facebook", paper presented at the Poke 1.0 - Facebook Social Research Symposium, University of London.

Selwyn, N. (2009),"Faceworking: exploring students' education-related use of Facebook", Learning, Media and Technology, Vol. 34, No. 2, pp. 157-174.

Stevens, J.P. (2002), Applied multivariate statistics for the social sciences, (4th ed.), Erlbaum, Hillsdale.

Thoene, W.S., (2012),"The impact of social networking sites on college students' consumption patterns", Master's thesis, Marshall University, West Virginia.

Thompson, C. (2007),"Brave new world of digital intimacy", New York Times Magazine, available at: www.nytimes.com/2008/09/07/magazine/07awareness.html?_r=1\& pagewanted=2/ (Accessed December 12, 2015).

Yeo, M.M.L. (2014),"Social media and social networking applications for teaching and Learning", European Journal of Science and Mathematics Education, Vol. 2, No. 1, pp. 53-62. 


\section{MMCKS Annex 1 - Research Questionnaire}

\section{Part 1 Demographic information of}

Put tick $(\checkmark)$ or write down wherever necessary.

1. Name

2. Gender :

Male/Female

3. Year of study:

$1^{\text {st }} / 2^{\text {nd }} / 3^{\text {rd }} / 4^{\text {th }}$ Year or semester

4. Age

5. Residence:

City/Village/Campus

6. Result (pls write down GPA): SSC:

$3^{\text {rd }}$ Year:

HSC:

1st Year: 2nd Year :

7. Use SNS (Social Networking Service): Facebook/Youtube/Blog/Twitter/Myspace/LinkedIn/

Others

8. First time use of SNS/ Facebook: date/year

9. Present usage: Yes/No

10. Computer usage for studies:

i) Communication (Skype, MSN, Others) ii) Communication (emailing with other students)

iii) Communication (Facebook, my space etc.) iv) Editing of documents. v) Communication

(emailing with teachers)

11. Use SNS/FB at: Home computer/Mobile/Laptop/University lab/Cyber café/

(Rank according to the extent of usage)

12. How many times do you log into SNS/ Facebook:

i) several times a day; ii) once a day; iii) several times a week; iv) at least once a week; v)once every couple of weeks; vi)once a month; vii)less than once a month; viii)only when a new notification had been made.

13. How much time (daily) do you pass using SNS for your study purpose:

14. How much time (daily) do you pass online:

15. Number of Facebook /SNS friends:

16. Cost of internet connection (average per month):

17. Monthly income:

18. Sources of income: Own/Others (pls mention):

(N.B. 5= Strongly Agree (SA), 4= Agree (A), $3=$ Neutral (N), 2 = Disagree (D), and $1=$ Strongly Disagree (SD))

\section{Part 2: Students' Academic Engagement with SNS}

\begin{tabular}{|c|c|c|c|c|c|c|}
\hline SL & Statement of the Factor & 1 & 2 & 3 & 4 & 5 \\
\hline 1 & Use of SNS for communication with students about studies & & & & & \\
\hline 2 & Use of SNS to communicate with other teachers about studies & & & & & \\
\hline 3 & SNS can be used for sharing academic information & & & & & \\
\hline 4 & $\begin{array}{l}\text { SNS can be a useful mode of sharing learning experiences and } \\
\text { research findings }\end{array}$ & & & & & \\
\hline 5 & Sharing academic events/notices & & & & & \\
\hline 6 & $\begin{array}{l}\text { SNS can be used for getting latest information related with my } \\
\text { studies/ educational developments/opportunities and current affairs }\end{array}$ & & & & & \\
\hline 7 & $\begin{array}{l}\text { SNS is mainly used for the purpose of searching friends and later } \\
\text { contact }\end{array}$ & & & & & \\
\hline 8 & Use of SNS for getting new academic ideas & & & & & \\
\hline
\end{tabular}

Vol. 11, No. 1, Spring, pp. 380-393, ISSN 1842-0206 | Management \& Marketing. Challenges for the Knowledge Society 


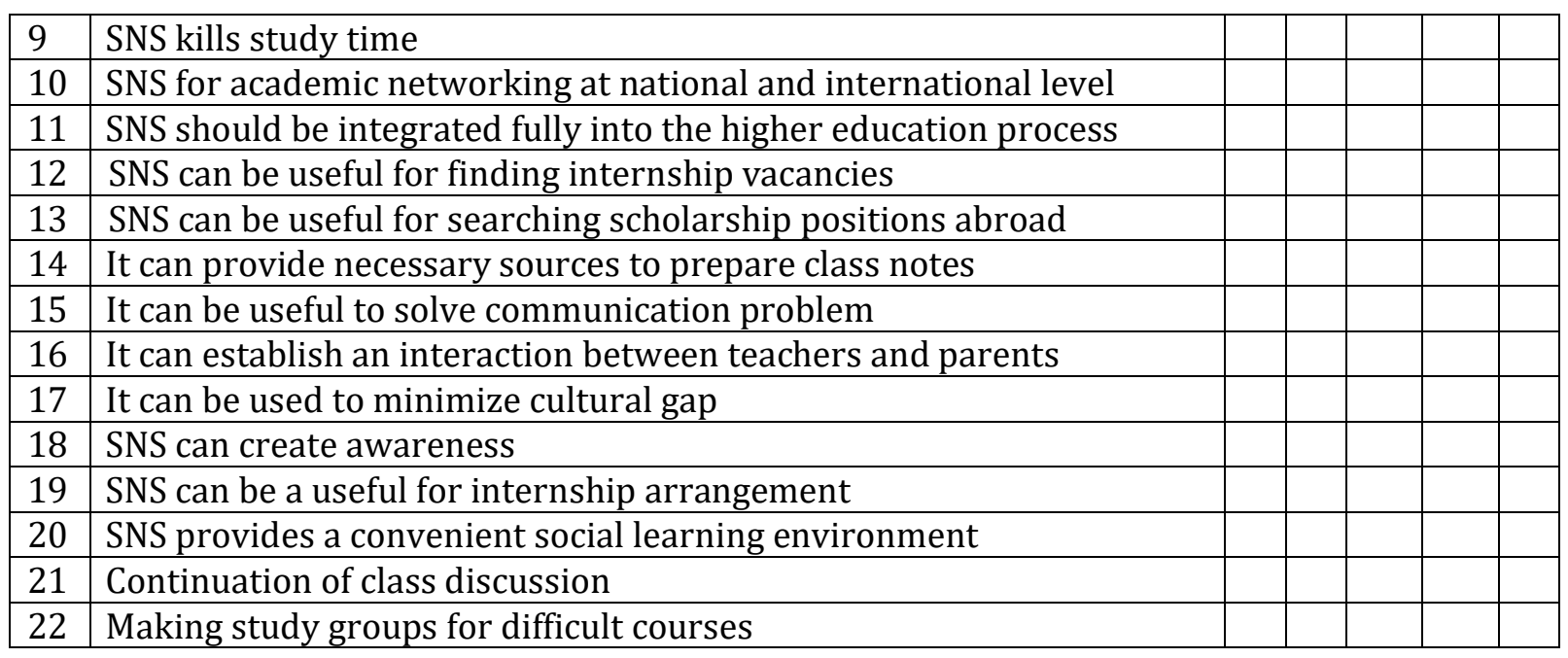

\section{Part 3: Social Capital}

\begin{tabular}{|c|c|c|c|c|c|c|}
\hline SL & Statement of the Factor & 1 & 2 & 3 & 4 & 5 \\
\hline 1 & Knowing a lot of friends through using SNS & & & & & \\
\hline 2 & Friends on SNS can help in solving many practical problems & & & & & \\
\hline 3 & Using SNS is an effective way to broaden social networks & & & & & \\
\hline 4 & SNS reduces the capability of social interactions & & & & & \\
\hline 5 & SNS is very helpful to arrange social events & & & & & \\
\hline 6 & SNS is very effective to build up public opinion & & & & & \\
\hline 7 & SNS encourages rumors & & & & & \\
\hline
\end{tabular}

\section{Part 4: Social Inclusion}

\begin{tabular}{|c|c|c|c|c|c|c|}
\hline SL & Statement of the factor & $\mathbf{1}$ & 2 & 3 & 4 & 5 \\
\hline 1 & I think I am outgoing(friendly) & & & & & \\
\hline 2 & I have different speaking styles in SNS and daily life & & & & & \\
\hline 3 & SNS is helpful for us to know a person from different perspective & & & & & \\
\hline 4 & SNS is helpful to find friends in the same country & & & & & \\
\hline 5 & I am more active in SNS than in real life & & & & & \\
\hline 6 & SNS is helpful to find old friends & & & & & \\
\hline
\end{tabular}

\section{Thank you}

